\title{
THE DISCREPANCY EVALUATION MODEL IN THE IMPLEMENTATION OF ONLINE LEARNING (ON THE BASIS OF PARENTS' PERCEPTIONS)
}

\author{
B. Bulkani', M. A. Setiawan ${ }^{2}$ \\ Muhammadiyah University of Palangkaraya, Palangkaraya, Indonesia. \\ E-mail: ${ }^{1}$ bulkaniardiansyah@gmail.com; ${ }^{2}$ andisetiawan@umpr.ac.id
}

W. Wahidah

State Junior High School 6 Palangkaraya, Palangkaraya, Indonesia. E-mail: wahidahlambri@gmail.com

\begin{abstract}
Introduction. The evaluation of online learning is an attempt to see the extent of the education process in Indonesia. This evaluation study seen from parents' perception is a new study that has not been carried out. Most dominant researchers evaluate the learning process by emphasising the school, but it has not been touched from the parent's side.

Aim. This study aims to evaluate the implementation of online learning based on the perceptions of parents of students.

Research methodology and methods. A discrepancy evaluation model method is used in the present research. The discrepancy evaluation model embodies five stages of evaluation: reviewing designs and standards, comparing implementation strategies, reviewing whether the process produces goals, comparing discrepancies with objectives, and cost and benefit analysis. The research subjects were 231 parents, who were involved using a simple random sampling technique. Data were collected using online questionnaires and interview sheets. A table of evaluation criteria and descriptive analysis were employed to analyse the data.

Results and scientific novelty. The study results show that the implementation of online learning can run well, but the government needs to prepare appropriate policies to maintain the quality of learning. On average, $72.82 \%$ of parents think that the online learning process is sufficient. There are still psychological obstacles in the form of fatigue, anxiety, too many tasks, and technical obstacles in the form of a slow Internet network and the lack of availability of online learning facilities such as cellphones, laptops, personal computers, which are input and follow-up devices for schools, so that online learning is expected to continue to be improved increasing its effectiveness.

Practical significance. This research implies that evaluation is one of the indicators that can measure the success of a programme. To implement the online learning programme, namely in junior high schools in Indonesia, it is necessary to have a special education policy by paying attention to the segmentation of the characteristics of parents, especially groups of low-income parents and education level.
\end{abstract}

Keywords: discrepancy evaluation model, online learning, parents' perception.

Acknowledgements. This study was supported by the Muhammadiyah University of Palangkaraya Research and Community Service Institute

For citation: Bulkani B., Setiawan M. A., Wahidah W. The discrepancy evaluation model in the implementation of online learning (on the basis of parents' perceptions). The Education and Science Journal. 2022; 24 (2): 116-137. DOI: 10.17853/1994-5639-2022-2-116-137 


\title{
МОДЕЛЬ ОЦЕНКИ РАСХОЖДЕНИЙ ПРИ ОСУЩЕСТВЛЕНИИ ОНЛАЙН-ОБУЧЕНИЯ (НА ОСНОВЕ ВОСПРИЯТИЯ РОДИТЕЛЕЙ)
}

\author{
Б. Булкани 1 , М. А. Сетиаван ${ }^{2}$ \\ Университет Мухамиадии в Палангкарая, Палангкарая, Индонезия. \\ E-mail: ${ }^{1}$ bulkaniardiansyah@gmail.com; ${ }^{2}$ andisetiawan@umpr.ac.id
}

В. Вахида

Государственная неполная средняя школа 6 Палангкарая, Палангкарая, Индонезия. E-mail: wahidahlambri@gmail.com

\begin{abstract}
Аннотация. Введение. Оценивание онлайн-обучения - это попытка увидеть масштабы образовательного процесса в Индонезии. Данное оценочное исследование, основанное на восприятии родителей, явцяется новым, ранее подобное не проводимось. Большинство ведущих ученых рассматривают процесс обучения, делая акцент на школе, но мнение родителей не учитывают.

Цель. Настоящая работа направлена на оценку реализации онмайн-обучения на основе восприятия родителей учащихся.

Методология и методы исследования. В исследовании используется метод оценки расхождений, включающий пять этапов: обзор проектов и стандартов; сравнение стратегий реализации; проверка того, приводит ми процесс к целям; сравнение несоответствий с целями; анализ «затраты - выгоды». Объект исследования - 231 родитель, опредеменный методом простой случайной выборки. Данные были собраны с помощью онлайн-анкет и опросных мистов. Таблица критериев оценки и описательный анализ были использованы дмя обработки данных.

Результаты и научная новизна. Результаты исследования показывают, что внедрение онлайн-обучения может идти успешно, но правительству необходимо подготовить соответствующую политику дмя поддержания качества образования. В среднем 72,82 \% родителей считают, что онлайн-обучения достаточно. По-прежнему существуют психологические препятствия в виде усталости, беспокойства, слишком большого количества заданий и технические препятствия в виде медленной и/или нестабильной работы сети Интернет и отсутствия возможностей для онлайн-обучения, таких как мобильные телефоны, ноутбуки, персональные компьютеры, которые явцяются необходимыми инструментами для школ, чтобы продолжать работу по улучшению онлайн-образования, повышая эффективность данного формата обучения.
\end{abstract}

Практическая значимость. Настоящее исследование подразумевает, что оценивание является одним из показателей, который может измерить успех программы. В рамках реализуемой программы, а именно в неполных средних школах Индонезии, при онлайн-обучении необходимо иметь специальную образовательную политику, уделяя внимание сегментации характеристик родителей, особенно групп с низким доходом и уровнем образования.

Ключевые слова: модель оценки расхождений, онлайн-обучение, восприятие родителей. 
Благодарности. Данное исследование было проведено при поддержке Института исследований и общественных работ Университета Мухаммадия в Палангкарае.

для иитирования: Булкани Б., Сетиаван М. А., Вахида В. Модемь оценки расхождений при осуществлении онлайн-обучения (на основе восприятия родителей) // Образование и наука. 2022. T. 24, № 2. C. 116-137. DOI: 10.17853/1994-5639-2022-2-116-137

\section{Introduction}

The current state of the COVID-19 pandemic has forced the entire education system to change. UNESCO data quoted by the BBC News Indonesia news agency, more than 1.6 billion children, who make up 90\% of the world's student population, are forced to study from home or are even threatened with dropping out of school [1]. The most noticeable change is the learning system, which was originally implemented face-to-face, to online learning. Some call it emergency online learning [2]. The impact of this change occurs in the planning, implementation, and evaluation of learning in schools [3]. The COVID-19 pandemic in Indonesia is a challenge for the Ministry of Education and Culture. The Ministry of Education and Culture is expected to carry out the educational process well even though the education process is carried out without face to face. Until now, COVID-19 has not been handled properly in several countries, one of which is Indonesia. The evidence that COVID-19 has not been handled properly can be seen from the transmission curve that has not been sloping. A flattened epidemic curve is a parameter that proves that the pandemic can be handled [4]. This development has consequences for the world of education, among others, that the online learning process may still be needed in the future. Even if the COVID-19 pandemic has ended, the world of education is faced with a new normal era, in which the online interaction process is still needed, or at least using the blended learning model as a rational choice. Blended learning is even believed to be one of the important efforts to improve the quality of learning [5]. For the learning process to be measurable, an evaluation process is needed.

Evaluation provides a better picture of the programme being implemented and the appropriate improvement plans to achieve programme objectives. In Indonesia, the evaluation process cannot run well because teachers do not fully understand information technology. It was found that $67 \%$ of teachers in Indonesia still stuttered in the use of information technology, and only about $3 \%$ of teachers stated that there were no such obstacles. Another problem that is often faced is network connectivity [6]. Internet network problems often occur when students have a place to live in rural areas. These constraints make online learning less effective. This condition is the cause of the learning process, and the evaluation process cannot run optimally. When the evaluation is not carried out properly, it will impact the quality of education, which cannot be measured 
properly. The quality of education will be measured properly if the right evaluation is carried out. From some of the descriptions above, it is necessary to conduct evaluation research on how to evaluate the implementation of online learning based on parents' perceptions so that policies that focus on segmenting parents with certain characteristics can be determined. This research is important as an evaluation material to determine the next step in optimising educational services in schools, and in general, it is also useful as a comparison material for schools. From the study results, it is hoped that there will be a direction of segmentation of communication policies, socialisation, and assistance to parents.

\section{Literature Review}

Nowadays, learning can not only be done face-to-face but can be done online. Online learning is instructions delivered on digital devices to support learning activities [7]. Dhawan explained that online learning is carried out in a synchronous or asynchronous environment using different devices such as mobile phones, laptops, or others with internet access [8]. Online learning facilitates so that the learning process can still be carried out even though it does not have to be face-to-face [9]. Along with the progress of the times and because of the existing conditions, online learning is growing rapidly [10]. Teachers as agents of change need to pay close attention to education development [11]. Meanwhile, online learning provides facilities so that learning can be carried out properly. Effective online learning improves several works, principles, prototypes, theories, ethics, and assessments following quality online learning standards. Online learning will be effective if it involves all internal and external components and potentials. Online learning must contain four effective learning components: discursive, adaptive, interactive, and reflective [12]. Good online learning must also be more flexible to accommodate the environmental situations faced by students and their parents. Online learning integrated with environmental conditions will foster positive feelings. The existence of obstacles to online learning raises many questions about its effectiveness, so it needs to be evaluated thoroughly and continuously. This evaluation is very important as input and improvement of the online learning process, especially parents who supervise their children studying at home during the pandemic.

Evaluation is collecting data to determine how goals can be achieved. Evaluation means systematically collecting facts to determine whether there has been a change in reality and the extent of the existing change [13]. The discrepancy evaluation model is an evaluation that emphasises the existing gaps [14]. These differences form the basis for evaluating the discrepancy model [15]. The discrepancy model involves differences from the evaluation results obtained and is used to determine the purpose of the evaluation [16]. The discrepancy evaluation aims 
to determine which components are dissimilar in a standard and whether there are differences. The evaluation aims to determine the next step of implementing a programme so that the programme is expected to be better [17]. Evaluation is used in education because evaluation is a process that determines the conditions under which a goal is achieved [18]. Evaluation serves as a way to improve the situation and perfect a programme, which is useful, among others, for users, including parents of students [7, 8]. Evaluation provides data for quality assurance and quality improvement activities [21] and provides information for retrieval about programme sustainability [22]. Learning evaluation motivates parents to participate more actively in the learning process [23] and help their children learn better [24]. Evaluation of learning can even function for students and parents to increase their respective roles in overcoming learning difficulties and planning for the future [25].

Evaluation of online learning can be done in various ways. Evaluators can be assigned from internal or external parties of the school. Also, other parties can be involved as data collectors or respondents. In this sense, the school can conduct the evaluation but use external parties as data collectors and respondents. The respondent can be an expert in evaluation or not [26]. In this context, parents can act as external respondents, who assess the success of online learning programmes. The advantages of external evaluators are their higher objectivity, while the weakness is that their knowledge is very varied and not too deep about the effectiveness of learning [27]. However, parents are the most involved in implementing their children's online learning at home during the pandemic so that their experiences, observations, and opinions can be used as evaluation data. Evaluation of online learning programmes can be done in several ways. Among other things is the evaluation of the Kirkpatrick model, which is generally used to measure behaviour change due to a training programme [28]. Learning evaluation can also be done using the center to study the evaluation University of California in Los Angeles (CSE-UCLA) model [29]. In addition, there is also a CIPP evaluation model (Context, Input, Process, Product), which was later developed into a Context, Input, Proses, Output dan Outcome (CIPPO) model by adding an Outcome element as a compliment. The CIPP and CIPPO models are considered quite comprehensive models because they evaluate a programme comprehensively $[20,21]$. However, the evaluation model widely and commonly used is the discrepancy model developed by Malcolm Provus. The evaluation research model on the implementation of online learning through parents' perceptions can be classified into the evaluation of the Stake model. The basis for choosing this model is because this evaluation model is oriented to the response and needs of programme participants' clients [32]. Parents of students are one of the clients in the learning programme, in which the evaluator must maintain a good relationship with them [33]. This evaluation can help students and parents identify their strengths and weaknesses in online learning. The main method is to measure and 
observe natural activities at home that students perform in online learning. This evaluation underlies the understanding that we can measure student learning activities at home through parents' opinions, observations, and perceptions.

Parental perception is one of the important components in determining the implementation of online learning [34]. The involvement of parents in educational activities affects student learning outcomes and creates positive perceptions in them [35]. Parents' perceptions of learning vary and provide different understandings and influences from one parent to another [36].

\section{Research Methods}

The research approach used in this research is evaluation research with a gap model. This study compares the gap between the established criteria and the results found. The flow of this research begins with the researchers' formulation of the problem by looking at the existing real conditions. The second stage is identifying and collecting research data to explore research findings. The third stage is research data analysis. The fourth stage presents research data to find out the research process results.

\begin{tabular}{|c|}
\hline $\begin{array}{c}\text { Planning an online learning programme } \\
\text { during the COVID-19 pandemic }\end{array}$ \\
\hline $\begin{array}{c}\text { The process of implementing online learning } \\
\text { during the COVID-19 pandemic }\end{array}$ \\
\hline $\begin{array}{c}\text { Analysis of the suitability of online learning } \\
\text { objectives during the COVID-19 pandemic }\end{array}$ \\
\hline
\end{tabular}

Stage of discrepancy evaluation model

1. Stage 1. Reviewing the design and standards of online learning programmes during the COVID-19 pandemic.

2. Stage 2. Compare implementation with design and standards.

3. Stage 3. Reviewing whether the process can produce programme objectives.

4. Stage 4. Compare whether there is overall discrepancy and review whether the goals have been achieved.

5. Stage 5. Analyse costs and benefits.

Fig. 1. Stage research model 


\section{Research stages}

The following are the stages of the conformity model evaluation process:

Stage 1. Review the design and standards of online learning programmes.

The researchers analysed the design of the learning programme during the COVID-19 pandemic, which contained the objectives, programme participants, and the basis for implementing the programme. The learning process carried out by educators is also a tangible form of school strategy, namely the strategy owned by the school, in order to support the school's vision and mission, namely "Parents as a Partner", where schools have a desire to make parents as partners for teachers. The school hopes every parent will be a spectator and simply know what the school programme is taught. More than that, the school wants every parent to be a partner who, together with the teacher, educates students and supports every school programme. Implementing the programme requires parents to understand and provide input to carry out online learning according to existing regulations and achieve predetermined educational goals.

Stage 2. Compare implementation with design and standards.

The online learning process is carried out regularly every week by utilising appropriate learning media. The preparation process is carried out by (1) giving announcements to students and parents of students that a learning process will be held. The announcement will then be posted on the parent, and teacher communication book, uploaded via the school's official social media (Instagram, Facebook, and school applications), (2) the teacher prepares learning materials. The next process is the discussion of the material by the teacher of each level. Based on interviews with teachers, in this discussion, each teacher in each class conveys to the teacher representatives, who will enter the meeting to discuss the things that need to be conveyed to the parents of students. If there is an additional announcement from the school, the principal will convey it to the teacher before the meeting. When there are matters related to administration, the education staff will convey them to teachers and parents. Based on the findings in the field, it can be seen that the observations, almost all parents of students who were present, came on time even before the implementation hours began. The programme runs for 30 minutes. However, in the observations made, several times the implementation, the programme runs more than the allotted time.

Stage 3. Reviewing whether the process can produce programme objectives.

In the third stage of evaluating this gap, it is necessary to determine whether the expected goals have been achieved. This stage is called the "collecting data from programme implementation" stage. 
Stage 4. Compare whether there is an overall discrepancy and review whether the objectives have been achieved.

The fourth stage is conduction of data analysis and determination of the output level obtained. The condition that must be considered in stage four is to see the programme extent and determine the direction of improvement.

Stage 5. Analyse costs and benefits.

The fifth stage is the stage of comparing the results achieved with the goals set. At this stage, the evaluator writes down all the gap findings to the decision-maker to decide on the programme continuation.

\section{Research subject}

The subjects of this study were parents of students in several schools in Indonesia, with 231 parents who were taken randomly. In this study, the following schools were involved: State Junior High School 6 Palangkaraya, State Junior High School 1 Katingan, State Junior High School 1 Kuala Kapuas, State Junior High School 1 Seruyan, and State Junior High School 1 Pulang Pisau. The selected junior high school is a school that has superior accreditation from the Indonesian Middle School Accreditation Board.

\section{Data collection instrument}

Collecting data is done by using an online questionnaire consisting of 35 items and measuring parents' perceptions about the implementation of online learning. Interview sheets are also used to explore online learning that the teacher has carried out to students whose parents review. This questionnaire was adapted from an instrument used by principals and supervisors to evaluate teacher performance in online learning. This questionnaire has been through expert testing and empirical testing with internal reliability of 0.71 . This questionnaire contains four aspects related to the effectiveness of the implementation of online learning, namely aspects of preparation, aspects of implementation, aspects of parental assistance, and aspects of barriers.

\section{Research data analysis}

Data analysis used descriptive analysis based on percentage, average percentage, and average perception score. Researchers tested the hypothesis about differences in parents' perceptions of online learning using several indicators: parenting, employment, income, and parents' education level. The difference test was carried out using a one-way analysis of variance (ANOVA one way) at a significance level of $5 \%$ and with the help of the SPSS version 20 program [37]. 


\section{Results}

\section{Parents' perceptions}

The online questionnaire results given to parents of students are 35 question items, the distribution of scores is between 10-35, with an average score of 26, 12, a standard deviation of 5, 24, and skewness of -0.61. Generally, parents have a positive perception of the implementation of online learning by teachers in schools. An average of 26.12, a positive perception, indicates that parents' perception of online learning is positive. The perception value score can be seen from the skewness value of the score distribution, which is -0.61 . A negative skewness number indicates a tendency for the curve to slant to the right, so it means that the score tends to be high. The absolute skewness value of 0.61 also indicates that the distribution of parental perception scores about the implementation of online learning is close to the Normal distribution. Table 1 demonstrates the percentage of parents, who responded to question items based on online learning aspects.

Table 1

Average percentage by perception dimension

\begin{tabular}{lll}
\hline No. & Dimension & The average percentage of positive answers \\
\hline 1. & Preparation aspect & 79,89 \\
2 & Implementation aspects & 84,20 \\
3. & Aspects of parental assistance & 77,07 \\
4 & Barrier aspect & 50,11 \\
\hline
\end{tabular}

Judging from the aspect of learning preparation, most of the parents of students have a positive perception. On average, $79.89 \%$ of parents stated that teachers have been able to carry out online learning preparation well. Things that need to be improved are communication between teachers and parents to prepare for learning, for example, information about which students need intensive assistance from parents. From the description of the data above, it can also be concluded that parents tend to have very positive perceptions on items that ask about the implementation of online learning. Parents' perceptions show that, in general, teachers in schools in Indonesia can carry out online learning well. Activities that received very positive perceptions include providing electronic teaching materials, good and appropriate spoken language, and applying two-way communication in online learning. In contrast, body language (gestures) still needs to be improved, reducing student boredom.

From the aspect of mentoring, it turns out that not all parents can accompany students during online learning. On average, only $77.07 \%$ of parents fulfill this aspect. Only $61.00 \%$ of parents stated that they always accompany their children's online learning activities. The analysis results still need to be 
improved through socialisation and communication between teachers and parents. From the aspect of online learning barriers, an average of $50.11 \%$ of parents think that their children do not experience online learning, while the remaining $49.89 \%$ of parents feel obstacles. These obstacles include psychological constraints (anxiety, fatigue, burdened with tasks) and technical obstacles such as lack of supporting facilities at home. That is why only $19.48 \%$ of parents support the continuation of online learning if the COVID-19 pandemic ends. In other words, $80.52 \%$ of parents want their children to return to school as usual if the COVID-19 pandemic ends.

\section{Differences in perceptions between fathers, mothers, and guardians of students}

The respondents studied consisted of biological fathers, biological mothers, and guardians of students. Based on the study results, the group of respondents as biological mothers was $52 \%$, biological fathers were $42 \%$, and guardians were $6 \%$. Thus, the comparison between the characteristics of the respondents is not too far away and relatively homogeneous. From the results of the different tests using one-way analysis of variance (ANOVA one way), the value of $F(2.228)=0.520$ with a significance of 0.595 was obtained. The analysis results on the population showed a significance level of 0.05 or $5 \%$; thus, there was no difference in perception between fathers, mothers, and guardians of students. Parents and guardians relatively have the same view that learning has been going well.

\section{Differences in perception in terms of class differences of students}

Respondents were taken randomly, consisting of parents or guardians whose children attend school in grades VII, VIII, and IX. The distribution is that $40 \%$ of respondents are parents whose children attend class VIII, 32\% of parents whose children attend class VII, and $28 \%$ of parents whose children attend class IX. The analysis results show that most respondents are parents whose children attend class VIII. From the results of testing differences in perceptions in terms of class differences of students using one-way analysis of variance, the value of $\mathrm{F}(2.228)=1.679$ with a significance of 0.189 was obtained. At a significance level of 0.05 or $5 \%$, the difference in perceptions between parents whose children attend school in grades VII, VIII, and IX are not significant in the population.

\section{Differences in perception in terms of the type of work of parents}

The study results obtained an overview of the classification of the types of work parents of students. In the questionnaire, six choices of parental occupations were prepared, namely teacher civil servants, army/police civil 
servants, non-teacher/non-army/police civil servants, farmers, traders, and employers of other private sectors. However, from random sampling, there were no parents whose jobs were in the army/police because the portion of this work was very small in the population. Most of the respondents have other private employment backgrounds. Respondents are following the characteristics of the parent population of students. This group is those with irregular incomes, most affected by the COVID-19 pandemic, so, likely, this will also affect their perception of the implementation of online learning.

\section{Differences in perception in terms of parental income}

In this study, parental income is divided into several categories. The lowest category is income less than Rp. (Indonesian Rupiah) 1 million/month, and the highest is above Rp. 4 million/month. The description of the parents' monthly income turns out that $35 \%$ of the parents, who are respondents have an income of Rp. 1-2 million/month, followed by those who earn Rp. 2-3 million/ month as much as $24 \%$, income below Rp. 1 million/month as much as $20 \%$. The rest are parents who earn Rp. 3-4 million/month and above Rp. 4 million/ month. The variation in the amount of parental income per month is a factor that is considered quite important in the implementation of online learning because it relates to the ability of parents to provide online learning facilities at home, such as the availability of internet quotas. The different test results using one-way analysis of variance obtained the value of $F(4.226)=13.332$ with a significance level of 0.00. there are differences in perceptions about the implementation of online learning when viewed from variations in parental income. In other words, the variation in perception can be explained through variations in the type of work of the parents of students.

\section{Differences in perception in terms of parental education}

In this study, parental education is divided into several categories. Several categories were prepared through a questionnaire, from elementary school graduation to doctoral degree. The distribution of the parents' educational backgrounds of the students, who were involved as respondents, was divided into four categories. $46 \%$ of parents graduated from high school, $29 \%$ graduated from undergraduate programmes, $13 \%$ graduated from junior high school, and the remaining $12 \%$ completed elementary school. This distribution is quite varied and reflects the proportion of parental background in the population. The existence of variations in the level of parental education is a factor that is thought to affect differences in their perceptions of the implementation of online learning. From the analysis results using one-way analysis of variance, the test results table obtained the value of $\mathrm{F}(3.227)=19.960$, which is significant at the 
0.000 level. The analysis results show a significance level of 0.05 or $5 \%$, and it can be concluded that there are differences in parents' perceptions about the implementation of online learning when viewed from the differences in parents' education levels. The variation in the parental educational background can explain the variation in parental perception. The group of parents with undergraduate education is the group, which has the most positive perception about the implementation of online learning. Meanwhile, the parents with the elementary education group have the lowest perception, although it is still classified as a positive perception. There is a tendency, the higher the level of education of parents, the more positive their perceptions about the implementation of online learning.

\section{Compare whether there is an overall discrepancy and review whether the objectives have been achieved}

Evaluation criteria regarding the implementation of online learning, it can be concluded that the evaluation results are as follows:

Table 2

Testing evaluation criteria

\begin{tabular}{lllll}
\hline No. & Evaluation dimension & Criteria & Achievements & Conclusion \\
\hline 1. & Preparation aspect & $>61 \%$ & $79,89 \%$ & Achieved \\
2 & Implementation aspects & $>61 \%$ & $84,20 \%$ & Achieved \\
3. & Aspects of parental assistance & $>61 \%$ & $77,07 \%$ & Achieved \\
4 & Barrier aspect & $>61 \%$ & $50,11 \%$ & Not achieved \\
& Average & & $72,82 \%$ & Achieved \\
\hline
\end{tabular}

Table 2, based on parents' perceptions, shows that the online learning process in schools has been going well and effectively. On average, $72.82 \%$ of parents think that the online learning process is sufficient. There are still psychological and technical barriers, which are input and follow-up materials for the school so that online learning can continue to be improved and its effectiveness increased. In the population of parents of students, there is no difference in parents' perceptions about the implementation of online learning when viewed from the difference in their children's class levels. Parents and guardians whose children attend school in grades VII, VIII, and IX have the same view on implementing online learning. Based on parents' opinion, the implementation of online learning in grades VII, VIII, and IX is quite good.

The results of the perception difference test using one-way analysis of variance, where the determinant is the type of parental occupation, the $F$ value $(4.226)=$ 0.574 with a significance of 0.682 . The analysis results at a significance level of 0.05 or $5 \%$ there is no difference in parents' perceptions about the implementation 
of online learning. In other words, most of the parents of students made into the population have an equally positive perception of the implementation of online learning, and both parents come from the group of Civil Servants, Teachers, Civil Servants, Non-Teachers, farmers, traders, and employers of other private sectors. Differences in parents' work backgrounds are not a determinant or cause of parents' perceptions about the implementation of online learning.

In the descriptive analysis, it can be seen that the parent group causes the difference in perception. Parents show the most positive perception with income above IDR 4 million/month. Meanwhile, parents who earn less than Rp. 1 million/month are the lowest, although this perception is still included in the positive perception category. These results indicate that the high-income parent group tends to have a more positive perception than the low-income parent group. This phenomenon can be understood because the implementation of online learning at home is strongly influenced by the ability of parents to provide learning facilities and facilities for their children. Providing online learning facilities such as laptops and cellphones and internet quotas requires no small money.

\section{Analysis of costs and benefits}

Analysis of learning carried out online during the COVID-19 pandemic in schools in Indonesia shows that learning can still be carried out even though learning uses information technology-based media in an online atmosphere so that the learning process can run well. In terms of costs, students and parents are burdened with increasingly large internet quotas because the learning process utilises the Internet network. The use of information technology-based learning media greatly helps the smooth learning process carried out in schools in Indonesia, but in some areas that still do not have an internet network, there will be obstacles in the online education process.

\section{Discussion}

The study results show that the online learning design carried out by teachers during the COVID-19 pandemic can already be run by complying with the provisions of the government regarding the learning system by utilising e-learning. The learning process carried out utilises e-learning provided specifically by the Education office and also utilises various meet and conference support applications. The learning process is adjusted to face-to-face provisions without reducing the important components of the education process. Teachers carry out the educational process systematically from the planning stage to the end. The results of this study found that, in general, parents have a positive 
perception of the implementation of online learning that is carried out. Positive perception is characterised by a willingness to accept, justify, and approve the given stimulus. In the context of this research, the stimulus given is in the form of positive questions about the implementation of online learning. There are at least two factors that cause this positive perception. First, parents accept online learning as a necessity and a state of affairs. The COVID-19 pandemic has not been well controlled, has forced all parents to accept the obligation to study at home for their children through the online system. In this context, perception is formed functionally. Parents assume that the function of education services during a pandemic can only be carried out through online learning. The concept of online learning, which requires students to study at home, was responded to by parents to replace face-to-face learning. Thus, a positive perception is formed because of hope. Parents tend to expect that online learning will be effective so that educational goals for their children can still be achieved. Certain objects that become a person's goal can emphasise his/her perception [38].

Second, positive perception is influenced by the intensity of information. Humans will give perceptions following the demands of the surrounding environment. The main element of perception is attention, and there is a human tendency to pay more attention to objects and events generally accepted around them [39]. Stimulants in the form of information and the state of the COVID-19 pandemic tend to receive more attention because of their high intensity. More prominent stimulation tends to get more attention [40]. Socialisation and publications about the COVID-19 pandemic and its impacts through various mass media also helped shape this perception. Even now, there tends to be information overload about the pandemic.

The learning process carried out online by utilising e-learning-based learning media is designed according to face-to-face learning. However, the implementation process using e-learning, even though it follows face-to-face standards, has some weaknesses. Most of the students in several existing schools are still experiencing network problems. Learning activities carried out by teachers cannot be monitored because learning is carried out online. Most of the students do not understand the learning that the teacher has carried out. From the results of perceptions from parents, several obstacles were also found, namely in the form of psychological and technical barriers. Fatigue, boredom, and anxiety are common in children because the need to socialise and interact physically with their friends at school is not channeled. The COVID-19 pandemic has changed social stratification, which impacts changing patterns of social interaction, even being quite vulnerable for some communities [41]. During the COVID-19 pandemic, the pattern of social interaction changed from physical to virtual [42]. Virtual interaction patterns do not always satisfy the human desire 
to interact physically. It causes a loss of happiness or subjective well-being [43]. The need for interaction that is not channeled then becomes a psychological burden. The burden is added to the accumulation of homework that students must do. The number of homework factors is a stressor for students learning during the COVID-19 pandemic. The amount of homework becomes an obstacle to online learning and triggers adolescent anxiety [44].

This study indicates that the online learning process is carried out following the standard learning process, but differences are found in its implementation. The learning process in normal conditions is carried out face-to-face, but in this online learning, students face challenges for mastering the material and information technology skills in virtual learning. Judging from the process that has been carried out, it appears that in an online atmosphere, the teacher cannot fully control the class with the help of a virtual room. Teachers cannot carefully monitor every student who takes part in virtual learning. The analysis results related to parents' perceptions of online learning found that one factor influencing online learning is parental income. Parents with a higher monthly income tend to have a more positive perception than parents with lower incomes. This phenomenon can be interpreted that for parents with high incomes, online learning does not become an additional economic burden for them.

On the other hand, for the low-income group of parents, it causes additional expenses for them, although, on the other hand, there are some savings such as reduced transportation costs for children because they do not need to go to school. In general, parents need additional costs because their children have to study at home. Additional expenses occur because parents must also prepare adequate facilities such as laptops and cellphones for their children in online learning. This additional expense can be a burden for those on low incomes. Even though there is an internet quota subsidy policy from the Ministry of Education and Culture, online learning is considered to increase the economic burden on parents, so that the perception of this group is not very positive compared to the high-income group of parents. The effectiveness of online learning at home requires the commitment of parents to provide equipment [45]. Found that one of the causes of negative perceptions of parents about online learning is the increase in costs that students and their parents must incur. The long learning activities at home will increase households in Indonesia [46]. Family income can affect the amount of time provided to accompany children's learning activities at home. Low income generally causes the need to work for every family member. Zachary $\mathrm{C}$ determined that in low-income families in Indonesia, the possibility of becoming a low-income family is greater for families with members who do not work [47]. In the female workers from low-income communities, the number of hours they work positively affects their income [48]. 
On the other hand, the income of female workers has a relationship with the number of hours worked simultaneously with other factors such as the level of education of workers [49]. These phenomena indicate that low-income groups will spend more time working, so they have less time to guide their children's learning at home. The busyness of parents at work is a factor inhibiting the effectiveness of online learning from home [50]. The COVID-19 pandemic has a more dangerous effect [51].

Another factor that influences parental perception is the level of parental education. This study found that parents with undergraduate education have more positive perceptions than parents with lower education. Descriptive analysis proves that the higher parents' education level, the more positive their perception of online learning is. According to perception theory, descriptive analysis results show that perceptions tend to be tied to the stimulus context. Humans always try to find the context and series of structures from the stimuli received by the five senses. Even the tendency to group stimuli based on similarities and feelings of closeness is universal [52]. It should be understood that people with higher education are more familiar with information technology in their work and daily lives. Parents' perceptions become more positive as they become part of the technology. These results follow Suwarto and Fajri [53] research, which found that parents with higher education pay more attention to their children's learning activities at home than parents with lower level of education. Parents' level of education will affect their mindset in meeting their children's educational needs.

The finding of income factors and parents' education level as factors influencing perceptions has implications for education policy. Optimising the process and results of online learning that has been carried out so far, it is necessary to carry out more focused communication and socialisation. This communication and socialisation need to be improved in the group of parents with low income and education because this group of parents tends to have a less positive perception of the implementation of online learning. It is necessary to study the possibility of subsidising internet quotas in a more targeted manner, considering the segmentation targeting certain groups of parents. Groups of parents with low incomes and education levels need better attention from the government. Efforts to socialise and communicate with this group also need to be improved, especially regarding the importance of mentoring their children and overcoming psychological and technical barriers. It is also necessary to find a way of subsidising specifically for these groups. In addition, the existence of psychological barriers to students can be overcome by the teacher by giving proportionally.

The analysis results show that the online learning process can be carried out following the provisions of the existing learning process in general by paying attention to online learning procedures. Strict control is needed to maintain the 
quality of learning so that the learning atmosphere through the virtual room is not reduced. Online learning is a solution when there are social restrictions so that the learning process continues to run well. Online learning also keeps the learning process running even though it is not carried out directly in the classroom [54]. The results of this study are in line with the research conducted by Lee J. F. K. [55], who states that online learning is a face-to-face learning solution. However, it should be noted that many aspects affect the quality of online learning, including the quality of the available internet network. Aspects of assessing parents' perceptions show that parents' income, education, and occupations affect the online learning process carried out in Indonesia.

The Indonesian government needs to develop special policies when learning is done online. One of the government's efforts is to provide a special internet quota for the learning process [56]. The government can cooperate with internet network provider companies. Cooperation with internet network provider companies will help students get priority even though learning is carried out online [57]. This special policy is very helpful, especially for middle to lower economic levels students.

\section{Conclusions and Recommendations}

The implementation of online learning is quite effective and reaches the specified criteria. Based on the data analysis of parents of students, the implementation of online learning has been going well and effectively. On average, more than $70 \%$ of parents have positive perceptions about preparation, implementation, and mentoring. The drawback lies in the aspect of obstacles because only $50.11 \%$ of parents think that the online learning that is carried out does not experience obstacles. The obstacles faced include psychological constraints (fatigue, anxiety, too many tasks) and technical obstacles such as the availability of supporting facilities and facilities. The factors that determine and can explain the difference in parents' perceptions about the implementation of online learning are the parent's income factor $(F$ value $(4: 226)=13,332$, significance 0.000), and the parent's education level factor $(F(3: 227)=19,960$, significance 0.000). High-income parents tend to have more positive perceptions than low-income parents. Parents with undergraduate education tend to have more positive perceptions than parents with lower level of education. This study suggests that in carrying out the learning process in special conditions such as during the COVID-19 pandemic, the government needs to develop policies so that online learning can run more effectively.

On the other hand, parents need socialisation, especially about how to assist in learning and overcome psychological and technical barriers 
experienced by students. This intensive socialisation and communication can be done by taking into account the segmentation of parents based on their income level and education degree. Alternatives can also be provided by providing special subsidised assistance to students in need, and the provision of school assignments must be more proportional.

\section{References}

1. Dewi W. A. F. Dampak COVID-19 terhadap Implementasi Pembelajaran Daring di Sekolah Dasar. Edukatif: Jurnal Ilmu Pendidikan. 2020; 2 (1): 55-61. DOI: 10.31004/edukatif. v2i1.89 (In Indonesian)

2. Diningrat S. W. M., Nindya M. A., Salwa. Emergency online teaching: Early childhood education lecturers' perception of barrier and pedagogical competency. Cakrawala Pendidikan. 2020; 39 (3): 705-719. DOI: 10.21831/cp.v39i3.32304

3. Romanov E. V. Efficiency assessment of higher education institutions: Contradictions and paradoxes: Part I. Obrazovanie $i$ nauka = The Education and Science Journal. 2019; 21 (9): 9-48. DOI: 10.17853/1994-5639-2019-9-9-48 (In Russ.)

4. Adedoyin O. B., Soykan E. COVID-19 pandemic and online learning: The challenges and opportunities. Interactive Learning Environments. 2020; 0 (0): 1-13. DOI: $10.1080 / 10494820.2020 .1813180$

5. Tobing R. L., Pranowo D. D. Blended learning in French intermediate grammar learning: Is it effective? Roswita. Cakrawala Pendidikan. 2020; 39 (3): 645-649. DOI: 10.21831/ cp.v39i3.32035

6. Kataev M. Y., Korikov A. M., Mkrttchian V. S. Concept and structure of automated system for monitoring student learning quality. Obrazovanie $i$ nauka $=$ The Education and Science Journal. 2017; 19 (10): 30-46. DOI: 10.17853/1994-5639-2017-10-30-46 (In Russ.)

7. Ferri F., Grifoni P., Guzzo T. Online learning and emergency remote teaching: Opportunities and challenges in emergency situations. Societies. 2020; 10 (4): 1-18. DOI: $10.3390 /$ soc 10040086

8. Dhawan S. Online learning: A panacea in the time of COVID-19 crisis. Journal of Educational Technology Systems. 2020; 49 (1): 5-22. DOI: 10.1177/0047239520934018

9. Bovermann K., Bastiaens T. J. Towards a motivational design? Connecting gamification user types and online learning activities. Research and Practice in Technology Enhanced Learning. 2020; 15 (1): 1-18. DOI: 10.1186/s41039-019-0121-4

10. Abuhassna H., Al-Rahmi W. M., Yahya N., Zakaria M. A. Z. M., Kosnin A. B. M., Darwish M. Development of a new model on utilizing online learning platforms to improve students' academic achievements and satisfaction. International Journal of Educational Technology in Higher Education. 2020; 17 (1): 1-23. DOI: 10.1186/s41239-020-00216-z

11. de Jong P. G. Impact of moving to online learning on the way educators teach. Medical Science Educator. 2020; 30 (3): 1003-1004. DOI: 10.1007/s40670-020-01027-7

12. Quadrado J. C., Pokholkov Y. P., Zaitseva K. K. ATHENA: Contributing to development of higher education institutions for the digital age. Higher Education in Russia. 2021; 30 (1): 125-131. DOI: 10.31992/0869-3617-2021-30-11-125-131

13. Alvarez S., Bampasidou M., Solis D. Evaluating the impact of employing local tax collectors to improve state-level licensing program outcomes in Florida. Evaluation Review. 2019; 43 (1-2): 77-107. DOI: 10.1177/0193841X19865353

Образование и наука. Том 24, № 2. 2022 / The Education and Science Journal. Vol. 24, № 2. 2022 
14. Aaron P. G., Malatesha Joshi R., Gooden R., Bentum K. E. Diagnosis and treatment of reading disabilities based on the component model of reading: An alternative to the discrepancy model of LD. Journal of Learning Disabilities. 2008; 41 (1): 67-84. DOI: $10.1177 / 0022219407310838$

15. Manfredi R., Guazzini A., Roos C. A., Postmes T., Koudenburg N. Private-public opinion discrepancy. PLoS One. 2020; 15 (11): 1-24. DOI: 10.1371/journal.pone.0242148

16. Ponnusamy P., de Boor J., Müller E. Discrepancy between constant properties model and temperature-dependent material properties for performance estimation of thermoelectric generators. Entropy. 2020; 22 (10): 1-18. DOI: 10.3390/e22101128

17. Cranfield D., Tick A., Venter I. M., Blignaut R. J., Renaud K. Higher education students' perceptions of online learning during COVID-19 - A comparative study. Education Sciences. 2021; 11 (8): 1-17. DOI: 10.3390/educsci11080403

18. Feistauer D., Richter T. How reliable are students' evaluations of teaching quality? A variance components approach. Assessment and Evaluation in Higher Education. 2017; 42 (8): 1263-1279. DOI: 10.1080/02602938.2016.1261083

19. Johnson E. S., Zheng Y., Crawford A. R., Moylan L. A. Developing an explicit instruction special education teacher observation rubric. Journal of Special Education. 2019; 53 (1): 28-40. DOI: 10.1177/0022466918796224

20. Syzdykbayeva A. D., Izmagambetova R. K., Amirova A. S., Bainazarova T. B., Sadykova M. K. Formation of primary school children self esteem on the basis of criteria-based assessment. Obrazovanie $i$ nauka = The Education and Science Journal. 2021; 23 (7): 147-169. DOI: 10.17853/1994-5639-2021-7-147-169

21. Li K. C., Chang M, Wu K. H. Developing a task-based dialogue system for English language learning. Education Sciences. 2020; 10 (11): 1-20. DOI: 10.3390/educsci10110306

22. Divayana D. G. H., Sappaile B. I., Pujawan I. G. N., Dibia I. K., Artaningsih L., Sundayana I. M. An evaluation of instructional process of expert system course program by using mobile technology-based CSE-UCLA model. International Journal of Interactive Mobile Technologies. 2017; 11 (6): 18-31. DOI: 10.3991/ijim.v11i6.6697

23. Kallio H., Virta K., Kallio M. Modelling the components of metacognitive awareness. International Journal of Educational Psychology. 2018; 7 (2): 94-122. DOI: 10.17583/ ijep.2018.2789

24. Maison D., Darmaji D., Astalini, Kurniawan D. A., Sumaryanti., Perdana R. Supporting assessment in education: E-assessment interest in physics. Universal Journal of Educational Research. 2020; 8 (1): 89-97. DOI: 10.13189/ujer.2020.080110

25. Zantsi R. The evaluative role of legislatures in creating a responsive executive. African Evaluation Journal. 2020; 8 (1): 1-6. DOI: 10.4102/AEJ.V8I1.432

26. Kicherova M. N., Semenov M. Y., Zyuban E. V. Qualification assessment practices: New possibilities and constraints. Obrazovanie $i$ nauka $=$ The Education and Science Journal. 2021; 23 (7): 71-98. DOI: 10.17853/1994-5639-2021-7-71-98 (In Russ.)

27. Leeds D. M., Mokher C. G. Improving indicators of college readiness: Methods for optimally placing students into multiple levels of postsecondary coursework. Educational Evaluation and Policy Analysis. 2020; 42 (1): 87-109. DOI: 10.3102/0162373719885648

28. Tat O., Koyuncu İ., Gelbal S. The influence of using plausible values and survey weights on multiple regression and hierarchical linear model parameters. Journal of Measurement and Evaluation in Education and Psychology. 2019; 10 (3): 235-248. DOI: 10.21031/epod.486999 
29. Vokasi J. P., Gede D., Divayana H., Ganesha U. P., Adiarta A., Ganesha U. P. Development of CSE-UCLA evaluation model modified by using weighted product in order to optimize digital library services in higher education of computer in Bali. Jurnal Pendidikan Vokasi. 2018; 7 (3): 275-287. DOI: 10.21831/jpv.v7i3.13370

30. La Velle J., Dighe S. A transdisciplinary model of program outcomes for enhanced evaluation practice. Canadian Journal of Program Evaluation. 2020; 35 (1): 92-103. DOI: 10.3138/CJPE.61660

31. Supriyadi E., Indro H. Y., Priyanto E., Surwi F. Students' evaluation on teaching in vocational and technical schools. International Journal of Instruction. 2020; 13 (2): 621-636. DOI: $10.29333 /$ iji.2020.13242a

32. Martínez-Muñoz M., Arnau L., Sabaté M. Evaluation of a parenting training program, "limits", in a juvenile justice service: Results and challenges. Psychosocial Intervention. 2019; 28 (1): 1-10. DOI: 10.5093/pi2018a14

33. Abma T. A., Visse M., Hanberger A., Simons H., Greene J. C. Enriching evaluation practice through care ethics. Evaluation. 2020; 26 (2): 131-146. DOI: $10.1177 / 1356389019893402$

34. Tembo M. J., Studsrød I., Young S. Governing the family: Immigrant parents' perceptions of the controlling power of the Norwegian welfare system. European Journal of Social Work. 2021; 24 (3): 492-503. DOI: 10.1080/13691457.2020.1738349

35. Puccioni J., Froiland J. M., Moeyaert M. Preschool teachers' transition practices and parents' perceptions as predictors of involvement and children's school readiness. Children and Youth Services Review. 2020; 109 (March 2019): 104742. DOI: 10.1016/j. childyouth.2019.104742

36. Bell C. "Maybe if they let us tell the story I wouldn't have gotten suspended": Understanding Black students' and parents' perceptions of school discipline. Children and Youth Services Review. 2020; 110. DOI: 10.1016/j.childyouth.2020.104757

37. Fatchurahman M., Setiawan M. A., Karyanti K. The development of group healing storytelling model in multicultural counselling services in Indonesian schools: Examination of disciplinary cases. Obrazovanie $i$ nauka = The Education and Science Journal. 2021; 23 (4): 157-180. DOI: 10.17853/1994-5639-2021-4-157-180

38. Nurdin. Pengaruh Motivasi Belajar Dan Persepsi Atas Lingkungan Sekolah Terhadap Prestasi Belajar Ilmu Pengetahuan Sosial. Jurnal Cakrawala Pendidikan. 2016; 35 (1): 98-105. DOI: 10.21831/cp.v35i1.28269 (In Indonesian)

39. Sayin A., Kahraman N. A measurement tool for repeated measurement of assessment of university students' writing skill: Development and evaluation. Eğitimde ve Psikolojide Ölçme ve Değerlendirme Dergisi. 2020; 11 (2): 1-18. DOI: 10.21031/epod.639148

40. Mansouri F. Cultural, religious and political contestations: The multicultural challenge. New York, Cham: Springer; 2015. 230 p. DOI: 10.1007/978-3-319-16003-0

41. Kinefuchi E. 'Nature is healing': Environmental infodemic and the pitfall of dualism. Journal of Environmental Media. 2020; 1 (2): 31-38. DOI: 10.1386/jem_00024_1

42. Garcia G. L., Stevahn L. Situational awareness and interpersonal competence as evaluator competencies. American Journal of Evaluation. 2020; 41 (1): 107-124. DOI: 10.1177/1098214018814941

43. Yang P. Humanities education reform exploration and practice under outcomesbased Education (OBE). Obrazovanie $i$ nauka = The Education and Science Journal. 2020; 22 (2): 78-97. DOI: 10.17853/1994-5639-2020-2-78-97 
44. Bonacini L., Gallo G., Scicchitano S. Working from home and income inequality: risks of a 'new normal' with COVID-19. Journal of Population Economics. 2020; 34: 303-360. DOI: $10.1007 / \mathrm{s} 00148-020-00800-7$

45. Usol'tsev P. A., Shamalo N. T., Antipova P. E. Diagnostic purposes of education: Problems, strategies and solutions. Obrazovanie $i$ nauka = The Education and Science Journal. 2020; 22 (8): 11-40. DOI: 10.17853/1994-5639-2020- 8-11-40 (In Russ.)

46. Poerwanti J. I. S., Istiyati S. Context-based evaluation materials in elementary teacher education program: A developmental research. Journal of Turkish Science Education. 2019; 16 (3): 325-335. DOI: 10.12973/tused.10285a

47. Zachary C., Jones D. J., McKee L. G., Baucom D. H., Forehand R. L. The role of emotion regulation and socialization in behavioral parent training: A proof-of-concept study. Behavior Modification. 2019; 43 (1): 3-25. DOI: 10.1177/0145445517735492

48. Busacca L. A., Rehfuss M. C. Postmodern career counseling: A new perspective for the $21^{\text {st }}$ century. Alexandria: American Counseling Association; 2017. 471 p.

49. Manzanares M. C. S., Arribas S. R., Aguilar C. P., Queiruga-Dios M. Á. Effectiveness of self-regulation and serious games for learning stem knowledge in primary education. Psicothema. 2020; 32 (4): 516-524. DOI: 10.7334/psicothema2020.30

50. Romanov E. V. Institutional traps in the scientific and educational sphere: Nature and mechanism of elimination. Obrazovanie $i$ nauka $=$ The Education and Science Journal. 2020; 22 (9): 107-147. DOI: 10.17853/1994-5639-2020-9-107-147 (In Russ.)

51. Patton M. Q. Evaluation criteria for evaluating transformation: Implications for the Coronavirus Pandemic and the global climate emergency. American Journal of Evaluation. 2021; 42 (1): 53-89. DOI: 10.1177/1098214020933689

52. Wen W., Kawabata H. Impact of navon-induced global and local processing biases on the acquisition of spatial knowledge. SAGE Open. 2018; 8 (2): 1-9. DOI: $10.1177 / 2158244018769131$

53. Suwarto S., Fajri H. Persepsi Orang Tua Terhadap Proses Bimbingan Belajar. Jurnal SAP. 2018; 3 (1): 41-46. DOI: 10.30998/sap.v3i1.2735 (In Indonesian)

54. Hyndman B., Harvey S. Health and physical education teacher education 2.0: Preservice teachers' perceptions on developing digital twitter skills. Australian Journal of Teacher Education. 2019; 44 (2): 34-50. DOI: 10.14221/ajte.2018v44n2.3

55. Lee J. F. K. Experiential teacher education - Preparing preservice teachers to teach English grammar through an experiential learning project. Australian Journal of Teacher Education. 2019; 44 (1): 1-20. DOI: 10.14221/ajte.2018v44n1.1

56. Lin T. C., Sun Y. S., Chang S. C., Chu S. I., Chou Y. T., Li M. W. Management of abusive and unfair Internet access by quota-based priority control. Computer Networks. 2004; 44 (4): 441-462. DOI: 10.1016/j.comnet.2003.12.003

57. Budiman E., Hairah U. Decision making analysis for free internet quota assistance online learning during the COVID-19 Pandemic. In: IOP Conference Series: Materials Science and Engineering. 2021; 1071 (1): 12-23. DOI: 10.1088/1757-899x/1071/1/012023 


\section{Information about the authors:}

Bulkani Bulkani - Dr. Sci. (Education), Associate Professor, Head of the Daily Supervisory Board of the University of Muhammadiyah Palangkaraya, Muhammadiyah University of Palangkaraya; ORCID 0000-0001-7012-7056; Palangkaraya, Indonesia. E-mail: bulkaniardiansyah@gmail.com

Wahidah Wahidah - M. Sci. (Education), Principal of the State Junior High School 6 Palangkaraya, Palangkaraya 6 Public Junior High School; ORCID 0000-0002-6214-2149; Palangkaraya, Indonesia. E-mail: wahidahlambri@gmail.com

Muhammad Andi Setiawan - M. Sci. (Education), Junior Researcher and Lecturer in Guidance and Counselling Study Programme, Muhammadiyah University of Palangka Raya; ORCID 0000-0001-7678-4057; Palangkaraya, Indonesia. E-mail: andisetiawan@umpr.ac.id

Conflict of interest statement. The authors declare that there is no conflict of interest.

Received 05.10.2021; revised 09.01.2022; accepted for publication 12.01.2022.

The authors have read and approved the final manuscript.

\section{информачия об авторах:}

Бумкани Бумкани - доктор педагогических наук, доцент, гмава ежедневного наблюдательного совета Университета Мухаммадии в Палангкарая; ORCID 0000-0001-70127056; Палангкарая, Индонезия. E-mail: bulkaniardiansyah@gmail.com

Вахида Вахида - магистр педагогических наук, директор государственной неполной средней школы 6 Палангкарая; ORCID 0000-0002-6214-2149; Палангкарая, Индонезия. E-mail: wahidahlambri@gmail.com

Сетиаван Мухаммад Анди - магистр педагогических наук, младший научный сотрудник и преподаватель учебной программы по ориентации и консультированию Университета Мухаммадии в Палангкарая; ORCID 0000-0001-7678-4057; Палангкарая, Индонезия. E-mail: andisetiawan@umpr.ac.id

информация о конфликте интересов. Авторы заявляют об отсутствии конфмикта интересов.

Статья поступима в редакцию 05.10.2021; поступима после рецензирования 09.01.2022; принята к публикации 12.01.2022.

Авторы прочитали и одобрили окончательный вариант рукописи. 